Correspondence

Prashanth K.

prashi2k@gmail.com

Received 23 March 2008

Accepted 2 December 2008

\section{Phenotypic and genotypic assays for detecting the prevalence of metallo- $\beta$-lactamases in clinical isolates of Acinetobacter baumannii from a South Indian tertiary care hospital}

\author{
R. Uma Karthika, ${ }^{1}$ R. Srinivasa Rao, ${ }^{1}$ Suchismita Sahoo, ${ }^{1}$ P. Shashikala, ${ }^{2}$ \\ Reba Kanungo, ${ }^{2}$ S. Jayachandran ${ }^{1}$ and K. Prashanth ${ }^{1}$ \\ ${ }^{1}$ Department of Biotechnology, School of Life Sciences, Pondicherry University, R. Venkataraman \\ Nagar, Kalapet, Puducherry 605 014, India \\ ${ }^{2}$ Department of Clinical Microbiology, Pondicherry Institute of Medical Sciences, Puducherry 605 \\ 014, India
}

\begin{abstract}
Nosocomial infections caused by Acinetobacter baumannii often prove difficult to treat owing to their multiple drug resistance. Carbapenems play a pivotal role in the management of severe Acinetobacter infections. However, reports of carbapenem resistance have been increasing alarmingly due to production of a variety of carbapenemases including metallo- $\beta$-lactamases (MBLs). This study investigated by both phenotypic and genotypic assays the prevalence of MBLs in a total of 55 A. baumannii strains isolated from a South Indian tertiary care hospital. Random amplified polymorphic DNA (RAPD) genotyping and antimicrobial susceptibility testing for nine clinically relevant antibiotics was done for characterization of isolates. Phenotypic expression of MBLs was examined by a simple double disc synergy (DDS) test, and the presence of the most frequent MBL coding genes, bla $a_{\mathrm{IMP} 1}$ and bla $\mathrm{VIM}_{2}$, was checked by PCR. RAPD analysis generated six clusters of isolates and there was very little correlation between RAPD clusters and resistant profiles. Most of the isolates showed complete or high resistance to imipenem $(100 \%)$, meropenem (89\%), amikacin (80\%), cefotaxime (89\%) and ciprofloxacin (72\%). In addition, $44 \%$ of isolates showed a high MIC level $\left(\geqslant 16 \mu \mathrm{g} \mathrm{ml}^{-1}\right)$ for meropenem. Thirty-nine isolates (70.9\%) were positive for MBL production by the DDS test while b/a $a_{\mathrm{IMP} 1}$ gene amplification was seen only in 23 isolates (42\%). Interestingly, none of the isolates showed amplification of b/aviM2. Further investigations on DDS-positive/PCR-negative isolates by spectrophotometric assay showed MBL activity in most of the isolates, suggesting involvement of other genes. The high incidence of isolates possessing MBL activity in the present study represents an emerging threat of complete resistance to carbapenems among Acinetobacter spp. in India.
\end{abstract}

\section{INTRODUCTION}

Acinetobacter baumannii, one of the most important nosocomial pathogens with multiple drug resistance (MDR), is of great concern because of its intrinsic and acquired resistance mechanisms, limiting the treatment options (Navon-Venezia et al., 2005). Carbapenems are the drugs of choice for A. baumannii infections and are often used as a last resort (Yano et al., 2001). However, carbapenem-resistant A. baumannii producing carbapenemases has been isolated increasingly in recent times (Jones et al., 2005) and in particular a variety of IMP and VIM type metallo- $\beta$-lactamases (MBLs) have been detected and

Abbreviations: DDS, double disc synergy; MBL, metallo- $\beta$-lactamase; MDR, multiple drug resistance; RAPD, random amplified polymorphic DNA. grouped under the class B carbapenemases (Jeong et al., 2006; Yum et al., 2002; Da Silva et al., 2002). Since the first descriptions of MBLs in Acinetobacter spp., IMP and VIM types have been found to have a wide geographical occurrence (Walsh et al., 2005; Jones et al., 2005). Recently, a new type of MBL, SIM-1, has also been reported (Lee et al., 2005). MBL genes also have the propensity to disseminate quickly to other species of Gram-negative bacilli (Navon-Venezia et al., 2005; Peleg et al., 2005). Therefore, it is essential to rapidly screen and detect MBLs in Acinetobacter, which could help in modifying therapy and initiate effective infection control to prevent further dissemination (Hirakata et al., 1998).

Numerous Indian studies have documented the presence of MBLs in Pseudomonas aeruginosa (Jesudason et al., 2005; 
Mendiratta et al., 2005; Sarkar et al., 2006); however, to our knowledge only one study for phenotypic detection of MBLs in A. baumannii has been done in India (Gupta et al., 2006). The aim of this study was to determine both phenotypically and genotypically the prevalence of MBLproducing strains among MDR A. baumannii isolated from clinical specimens in this geographical region.

\section{METHODS}

Bacterial isolates. All the Acinetobacter isolates were obtained from a South Indian tertiary care hospital (Pondicherry Institute of Medical Sciences, Puducherry, India) from various clinical specimens, such as endotracheal aspirates, cerebrospinal fluid, wound swabs, urine and blood culture specimens, from patients admitted to the intensive care and acute medical care units from January to April 2007. All the replicates were excluded from the study. A total of 55 Acinetobacter isolates were identified and grouped into the Acinetobacter calcoaceticus-baumannii complex (Acb complex) using phenotypic tests as described elsewhere (Gerner-Smidt et al., 1991; Prashanth \& Badrinath, 2000; Kenchappa \& Sreenivasmurthy, 2003). A simple molecular method, namely amplified rDNA restriction analysis (ARDRA), was used to further identify genomic groups within the $A c b$ complex as described elsewhere (Chandra et al., 2002). ARDRA identified all the isolates from our collection as $A$. baumannii.

Antimicrobial susceptibility testing. Antimicrobial susceptibility testing was performed for nine different therapeutically relevant antibiotics by the Kirby-Bauer disc diffusion method according to Clinical Laboratory Standards Institute guidelines (CLSI, 2006). Antibiotics tested included amikacin $(10 \mu \mathrm{g})$, ceftazidime $(30 \mu \mathrm{g})$, cefotaxime $(30 \mu \mathrm{g})$, ceftriaxone $(30 \mu \mathrm{g})$, ciprofloxacin $(5 \mu \mathrm{g})$, cefepime $(30 \mu \mathrm{g})$, imipenem $(10 \mu \mathrm{g})$, meropenem $(10 \mu \mathrm{g})$ and netilmicin $(30 \mu \mathrm{g})$. A. baumannii ATCC $19606^{\mathrm{T}}$ was used as control. Isolates showing MDR were further tested for MBL production. MDR was defined as resistance to two or more drugs or drug classes of therapeutic relevance (Prashanth \& Badrinath, 2004; Navon-Venezia et al., 2005).

RAPD typing. Genotyping of A. baumannii isolates was performed using random amplified polymorphic DNA (RAPD) analysis for 48 isolates using arbitrary hexamers ( $\mathrm{H}$ series) obtained from Operon Technologies. The PCR mixtures $(10 \mu \mathrm{l})$ contained $1 \mu \mathrm{l}$ PCR buffer with $1.5 \mathrm{mM} \mathrm{MgCl}_{2}, 50 \mu \mathrm{M}$ each dNTP, 50 pmol primer, $1 \mathrm{U}$ Taq polymerase (Bangalore Genei) and $50 \mathrm{ng}$ DNA template. PCR amplifications were performed using a thermal cycler (Eppendorf) as follows: (i) initial denaturation step of $5 \mathrm{~min}$ at $94{ }^{\circ} \mathrm{C}$; (ii) 35 cycles of PCR, with each cycle consisting of $30 \mathrm{~s}$ at $94{ }^{\circ} \mathrm{C}, 45 \mathrm{~s}$ at $45{ }^{\circ} \mathrm{C}$ and $2 \mathrm{~min}$ at $72{ }^{\circ} \mathrm{C}$; and (iii) a final extension step of $5 \mathrm{~min}$ at $72{ }^{\circ} \mathrm{C}$. Amplified products from the isolates were analysed by electrophoresis on $1.2 \%(\mathrm{w} / \mathrm{v})$ agarose gels, stained with ethidium bromide and the banding patterns were analysed using the Quantity One Gel Doc 2000 (Bio-Rad) computer software system.

MIC determination and MBL detection. The MIC for meropenem was determined by the agar dilution method as recommended by the CLSI (2006). The organisms were considered susceptible to meropenem if the MIC was $\leqslant 4 \mu \mathrm{g} \mathrm{ml}^{-1}$ and resistant if the MIC was $\geqslant 16 \mu \mathrm{g} \mathrm{ml}^{-1}$ (CLSI, 2006). For phenotypic detection of MBLs among the A. baumannii strains, we used the imipenem EDTAdouble disc synergy (DDS) test developed by Yong et al. (2002). All the MBL-positive isolates were repeatedly checked for reproducibility. All the isolates were checked for MBL genotypically by PCR for the presence of the predominant genes $b a_{\mathrm{IMP} 1}$ and $b a_{\mathrm{VIM} 2}$. PCR conditions and $b l a_{\mathrm{IMP} 1}$ and $b l a_{\mathrm{VIM} 2}$ primers used for PCR amplification were according to previously described studies (Poirel et al., 2000; Yum et al., 2002). Isolates which were positive for MBL by the DDS test but PCR-negative were further tested for enzyme activity by spectrophotometry. The spectrophotometric assay for assessing MBL activity was performed as described previously (Edwards et al., 1998; Lauretti et al., 1999).

\section{RESULTS AND DISCUSSION}

In recent years, there have been numerous reports on MDR A. baumannii from hospital settings in India (Prashanth \& Badrinath, 2005, 2006; Sinha et al., 2007; Joshi et al., 2003b). In our earlier studies, we characterized isolates obtained mainly from intensive care units (Prashanth \& Badrinath, 2000, 2005), while this study attempted to determine the resistance among isolates obtained from various other medical wards also. In particular, 36 strains were isolated from wards outside the intensive care unit. Antibiotic susceptibility testing showed that the majority of the isolates were resistant to three or more antibiotics (Table 1). While all the isolates were resistant to imipenem, $89 \%, 80 \%, 89 \%$ and $72 \%$ of isolates were resistant to meropenem, amikacin, cefotaxime and ciprofloxacin, respectively. A. baumannii isolates also showed moderate resistance to ceftriaxone (42\%) and ceftazidime (36\%). Unfortunately, these are the antibiotics that are currently being prescribed in the hospital. However, a few antimicrobials, those that were not used frequently in the hospital, such as cefepime and netilmicin, continued to show low resistance, i.e. $30 \%$ and $27 \%$, respectively. Such observations have also been witnessed by other investigators wherein susceptibility is attributed to decreased usage of the antimicrobial (Manikal et al., 2000).

RAPD analysis of the A. baumannii isolates examined showed fragments ranging from 500 to 1500 bp (Fig. 1). An UPGMA dendrogram (data not shown) constructed using binary data generated six clusters from the isolates (designated $\mathrm{A}-\mathrm{F}$ ), revealing the genetic relatedness among the isolates. Two major clusters depicted in the dendrogram, namely $\mathrm{D}$ and $\mathrm{F}$, comprised 17 and 13 isolates, respectively. Cluster E had a total of nine isolates. The A, B and $\mathrm{C}$ clusters constituted only a few isolates (one to five isolates). RAPD results did not correlate with those of the antibiotypes since our isolates showed highly divergent resistance profiles and only a few correlations could be made in this regard. A few isolates belonging to certain clusters (A: P31, P49, P51; C: P39, P56; E: P46, P47; F: P15, P16) had identical resistograms (Table 1). Interestingly, cluster D had seven isolates showing two kinds of identical resistograms specific for the site of isolation [D1 (P5, P53, P55 all from endotracheal aspirates) and D2 (P32, P33, P36, P38 all from wounds)]. Such associations were also found in clusters $\mathrm{C}$ (wound) and $\mathrm{E}$ (urine), suggesting that distinct clones may be responsible for specific disease or infection caused by this organism. Although the discriminatory power of PFGE genotyping was found to be higher than that of PCR-based techniques, the present study 
Table 1. Origin, resistogram, MBLs and RAPD cluster of all the isolates of $A$. baumannii

\begin{tabular}{|c|c|c|c|c|c|c|c|}
\hline \multirow[t]{2}{*}{ Strain ID } & \multirow{2}{*}{$\begin{array}{c}\text { Site of } \\
\text { isolation }\end{array}$} & \multirow[t]{2}{*}{ Resistogram $\dagger$} & \multicolumn{3}{|c|}{ Metallo- $\beta$-lactamase } & \multirow{2}{*}{$\begin{array}{c}\text { Imipenem hydrolysis - spec- } \\
\text { trophotometric assay } \ddagger\end{array}$} & \multirow{2}{*}{$\begin{array}{l}\text { RAPD } \\
\text { cluster }\end{array}$} \\
\hline & & & DDS test & $\begin{array}{c}(\text { PCR }) \\
b l a_{\mathrm{IMP1}}\end{array}$ & $\begin{array}{c}\text { (PCR) } \\
\text { bla }_{\mathrm{VIM} 2}\end{array}$ & & \\
\hline P1 & Urine & $\mathrm{Ca}, \mathrm{Ce}, \mathrm{Ci}, \mathrm{Cf}, \mathrm{Cpm}, \mathrm{I}, \mathrm{M}$ & + & + & - & - & $\mathrm{D}$ \\
\hline $\mathrm{P} 2$ & Wound & $\mathrm{Ak}, \mathrm{Ca}, \mathrm{Ce}, \mathrm{Cf}, \mathrm{I}, \mathrm{M}$ & - & - & - & - & $\mathrm{C}$ \\
\hline P3 & Wound & $\mathrm{Ak}, \mathrm{Ce}, \mathrm{Cf}, \mathrm{I}, \mathrm{M}$ & + & + & - & - & $\mathrm{D}$ \\
\hline $\mathrm{P} 4$ & Wound & $\mathrm{Cf}, \mathrm{Ci}, \mathrm{I}, \mathrm{M}, \mathrm{Nt}$ & + & + & - & - & $\mathrm{D}$ \\
\hline P5 & ETA & $\mathrm{Ak}, \mathrm{Ce}, \mathrm{Cf}, \mathrm{I}, \mathrm{M}$ & - & + & - & - & $\mathrm{D}$ \\
\hline P6 & ETA & $\mathrm{Ak}, \mathrm{Ce}, \mathrm{Cf}, \mathrm{I}, \mathrm{M}$ & - & + & - & - & $\mathrm{D}$ \\
\hline P9 & Wound & $\mathrm{Ce}, \mathrm{Cf}, \mathrm{I}, \mathrm{Nt}, \mathrm{M}$ & - & + & - & $13.2 \mathrm{nmols}$ & $\mathrm{D}$ \\
\hline P10 & Wound & $\mathrm{Ak}, \mathrm{Ca}, \mathrm{Ce}, \mathrm{Cf}, \mathrm{I}, \mathrm{M}, \mathrm{Nt}$ & - & + & - & - & $\mathrm{C}$ \\
\hline P11 & Wound & $\mathrm{Ak}, \mathrm{Ce}, \mathrm{Cf}, \mathrm{Ci}, \mathrm{I}, \mathrm{M}$ & - & + & - & - & $\mathrm{D}$ \\
\hline P12 & ETA & $\mathrm{Ak}, \mathrm{Ce}, \mathrm{Cf}, \mathrm{I}, \mathrm{Nt}, \mathrm{M}$ & - & + & - & - & $\mathrm{D}$ \\
\hline P13 & Wound & $\mathrm{Ak}, \mathrm{Ce}, \mathrm{Cf}, \mathrm{Ci}, \mathrm{Cpm}, \mathrm{M}, \mathrm{I}$ & - & - & - & - & $\mathrm{F}$ \\
\hline P14 & Wound & $\mathrm{Ak}, \mathrm{Ce}, \mathrm{Cf}, \mathrm{Ci}, \mathrm{Cpm}, \mathrm{I}, \mathrm{M}, \mathrm{Nt}$ & + & - & - & $48.0 \mathrm{nmol}$ & $\mathrm{F}$ \\
\hline P15 & Wound & $\mathrm{Ak}, \mathrm{Ca}, \mathrm{Ce}, \mathrm{Ci}, \mathrm{Cpm}, \mathrm{M}, \mathrm{I}$ & + & - & - & $51.0 \mathrm{nmol}$ & $\mathrm{F}$ \\
\hline P16 & ETA & $\mathrm{Ak}, \mathrm{Ca}, \mathrm{Ce}, \mathrm{Ci}, \mathrm{Cpm}, \mathrm{I}$ & + & - & - & $53.6 \mathrm{nmol}$ & $\mathrm{F}$ \\
\hline P17 & ETA & $\mathrm{Ca}, \mathrm{Ce}, \mathrm{Cf}, \mathrm{Ci}, \mathrm{Cpm}, \mathrm{I}, \mathrm{M}$ & - & + & - & - & $\mathrm{F}$ \\
\hline P18 & Wound & $\mathrm{Ak}, \mathrm{Ce}, \mathrm{Cf}, \mathrm{Ci}, \mathrm{I}, \mathrm{M}$ & + & + & - & - & $\mathrm{F}$ \\
\hline P19 & CSF & $\mathrm{Ak}, \mathrm{Ce}, \mathrm{Cf}, \mathrm{I}, \mathrm{M}, \mathrm{Nt}$ & + & - & - & $52.8 \mathrm{nmol}$ & $\mathrm{F}$ \\
\hline P20 & Wound & $\mathrm{Ak}, \mathrm{Ca}, \mathrm{Cf}, \mathrm{I}, \mathrm{M}, \mathrm{Nt}$ & ND & - & - & - & $\mathrm{F}$ \\
\hline $\mathrm{P} 21$ & Wound & $\mathrm{Ak}, \mathrm{Cf}, \mathrm{Ce}, \mathrm{I}, \mathrm{M}, \mathrm{Nt}$ & ND & - & - & - & $\mathrm{F}$ \\
\hline $\mathrm{P} 22$ & Wound & $\mathrm{Ak}, \mathrm{Ca}, \mathrm{Ce}, \mathrm{Cf}, \mathrm{Ci}, \mathrm{Cpm}, \mathrm{I}, \mathrm{M}$ & + & + & - & - & E \\
\hline P23 & Wound & $\mathrm{Ca}, \mathrm{Ce}, \mathrm{Cf}, \mathrm{Ci}, \mathrm{Cpm}, \mathrm{I}, \mathrm{M}$ & + & + & - & - & $\mathrm{F}$ \\
\hline $\mathrm{P} 24$ & ETA & $\mathrm{Ak}, \mathrm{Ca}, \mathrm{Ce}, \mathrm{Cf}, \mathrm{I}, \mathrm{M}$ & + & + & - & - & E \\
\hline P25 & Blood & $\mathrm{Ca}, \mathrm{Ce}, \mathrm{Ci}, \mathrm{Cpm}, \mathrm{I}, \mathrm{M}$ & + & + & - & - & E \\
\hline P26 & Blood & $\mathrm{Ak}, \mathrm{Ca}, \mathrm{Ce}, \mathrm{Ci}, \mathrm{Cpm}, \mathrm{I}, \mathrm{M}$ & + & + & - & - & E \\
\hline P27 & ETA & $\mathrm{Ak}, \mathrm{Ce}, \mathrm{Cf}, \mathrm{I}, \mathrm{M}$ & - & - & - & $1.9 \mathrm{nmols}$ & E \\
\hline P28 & Urine & $\mathrm{Ak}, \mathrm{Ca}, \mathrm{Ce}, \mathrm{Cf}, \mathrm{I}, \mathrm{M}$ & + & - & - & $58.6 \mathrm{nmol}$ & $\mathrm{F}$ \\
\hline P29 & Urine & $\mathrm{Ak}, \mathrm{Ca}, \mathrm{Ce}, \mathrm{Cf}, \mathrm{Ci}, \mathrm{I}, \mathrm{M}, \mathrm{Nt}$ & + & - & - & $60.0 \mathrm{nmol}$ & B \\
\hline P30 & Wound & $\mathrm{Ak}, \mathrm{Ce}, \mathrm{Ci}, \mathrm{Cpm}, \mathrm{I}, \mathrm{M}$ & + & - & - & $57.2 \mathrm{nmol}$ & $\mathrm{C}$ \\
\hline P31 & ETA & $\mathrm{Ak}, \mathrm{Ce}, \mathrm{Cf}, \mathrm{I}, \mathrm{M}$ & + & - & - & $60.1 \mathrm{nmol}$ & $\mathrm{A}$ \\
\hline P32 & Wound & $\mathrm{Ak}, \mathrm{Ce}, \mathrm{Cf}, \mathrm{I}, \mathrm{M}, \mathrm{Nt}$ & + & - & - & $53.9 \mathrm{nmol}$ & $\mathrm{D}$ \\
\hline P33 & Wound & $\mathrm{Ak}, \mathrm{Ce}, \mathrm{Cf}, \mathrm{I}, \mathrm{M}, \mathrm{Nt}$ & + & - & - & No activity & ND \\
\hline P34 & CSF & $\mathrm{Ak}, \mathrm{Ce}, \mathrm{Cf}, \mathrm{Cpm}, \mathrm{I}, \mathrm{M}, \mathrm{Nt}$ & + & - & - & $46.3 \mathrm{nmol}$ & $\mathrm{D}$ \\
\hline P35 & $\mathrm{BT}$ & $\mathrm{Ak}, \mathrm{Ce}, \mathrm{Cf}, \mathrm{Cpm}, \mathrm{I}, \mathrm{M}, \mathrm{Nt}$ & - & - & - & - & $\mathrm{D}$ \\
\hline P36 & Wound & $\mathrm{Ak}, \mathrm{Ce}, \mathrm{Cf}, \mathrm{I}, \mathrm{M}, \mathrm{Nt}$ & + & - & - & $56.0 \mathrm{nmol}$ & $\mathrm{D}$ \\
\hline P37 & CSF & $\mathrm{Ak}, \mathrm{Ca}, \mathrm{Ce}, \mathrm{Ci}, \mathrm{I}, \mathrm{M}, \mathrm{Nt}$ & + & - & - & $56.4 \mathrm{nmol}$ & $\mathrm{D}$ \\
\hline P38 & Wound & $\mathrm{Ak}, \mathrm{Ce}, \mathrm{Cf}, \mathrm{I}, \mathrm{M}, \mathrm{Nt}$ & + & - & - & $42.7 \mathrm{nmol}$ & $\mathrm{D}$ \\
\hline P39 & Wound & $\mathrm{Ak}, \mathrm{Ce}, \mathrm{Cf}, \mathrm{Ci}, \mathrm{I}, \mathrm{M}$ & + & - & - & $41.6 \mathrm{nmol}$ & $\mathrm{C}$ \\
\hline P40 & Blood & $\mathrm{Ak}, \mathrm{Ca}, \mathrm{Ci}, \mathrm{Cpm}, \mathrm{I}, \mathrm{M}$ & + & - & - & $41.8 \mathrm{nmol}$ & $\mathrm{D}$ \\
\hline P41 & Sputum & $\mathrm{Ak}, \mathrm{Ca}, \mathrm{Ce}, \mathrm{Ci}, \mathrm{Cpm}, \mathrm{I}, \mathrm{M}$ & + & - & - & No activity & E \\
\hline $\mathrm{P} 42$ & Urine & $\mathrm{Ak}, \mathrm{Ce}, \mathrm{Ci}, \mathrm{Cpm}, \mathrm{I}$ & + & - & - & $43.1 \mathrm{nmol}$ & F \\
\hline $\mathrm{P} 43$ & Wound & $\mathrm{Ce}, \mathrm{Cf}, \mathrm{Ci}, \mathrm{I}, \mathrm{M}$ & + & - & - & $49.2 \mathrm{nmol}$ & F \\
\hline P44 & ETA & $\mathrm{Ce}, \mathrm{Cf}, \mathrm{Ci}, \mathrm{Cpm}, \mathrm{I}$ & + & - & - & $49.2 \mathrm{nmol}$ & ND \\
\hline P45 & Wound & $\mathrm{Ce}, \mathrm{Ci}, \mathrm{I}$ & + & - & - & $42.5 \mathrm{nmol}$ & $\mathrm{E}$ \\
\hline P46 & Urine & $\mathrm{Ca}, \mathrm{I}, \mathrm{M}$ & + & - & - & $43.1 \mathrm{nmol}$ & E \\
\hline P47 & Urine & $\mathrm{Ca}, \mathrm{I}, \mathrm{M}$ & + & - & - & $54.8 \mathrm{nmol}$ & $\mathrm{E}$ \\
\hline $\mathrm{P} 48$ & CSF & $\mathrm{Ak}, \mathrm{Ce}, \mathrm{Cf}, \mathrm{I}, \mathrm{M}$ & + & - & - & $57.0 \mathrm{nmol}$ & ND \\
\hline P49 & ETA & $\mathrm{Ak}, \mathrm{Ce}, \mathrm{Cf}, \mathrm{Ci}, \mathrm{I}, \mathrm{M}$ & + & - & - & $41.6 \mathrm{nmol}$ & A \\
\hline P50 & ETA & $\mathrm{Ak}, \mathrm{Ce}, \mathrm{I}, \mathrm{M}$ & + & - & - & $54.8 \mathrm{nmol}$ & ND \\
\hline P51 & ETA & $\mathrm{Ak}, \mathrm{Ce}, \mathrm{Cf}, \mathrm{Ci}, \mathrm{I}, \mathrm{M}$ & + & + & - & - & A \\
\hline P52 & ETA & $\mathrm{Ak}, \mathrm{Ce}, \mathrm{Cf}, \mathrm{I}$ & + & + & - & - & ND \\
\hline P53 & ETA & Ak, Ce, Cf, I & + & + & - & - & $\mathrm{D}$ \\
\hline P54 & Wound & $\mathrm{Ak}, \mathrm{Ce}, \mathrm{I}, \mathrm{M}$ & - & + & - & - & ND \\
\hline P55 & ETA & $\mathrm{Ak}, \mathrm{Ce}, \mathrm{Cf}, \mathrm{I}, \mathrm{M}$ & + & + & - & - & $\mathrm{D}$ \\
\hline P56 & Wound & $\mathrm{Ak}, \mathrm{Ce}, \mathrm{Cf}, \mathrm{Ci}, \mathrm{I}, \mathrm{M}$ & - & + & - & - & $\mathrm{C}$ \\
\hline P57 & ETA & $\mathrm{Ak}, \mathrm{I}, \mathrm{M}$ & - & + & - & - & ND \\
\hline
\end{tabular}

ND, Not determined.

${ }^{*} \mathrm{BT}$, Bone tissue; CSF, cerebrospinal fluid; ETA, endotracheal aspirate.

$\dagger \mathrm{Ak}$, Amikacin; Ca, ceftazidime; Ce, cefotaxime; Ci, ceftriaxone; Cf, ciprofloxacin; Cpm, cefepime; I, imipenem; M, meropenem; $\mathrm{Nt}$, netilmicin. $\ddagger$ Imipenem hydrolysed $\min ^{-1}$ (mg protein) $)^{-1}$.

$\S$ Negative control. 


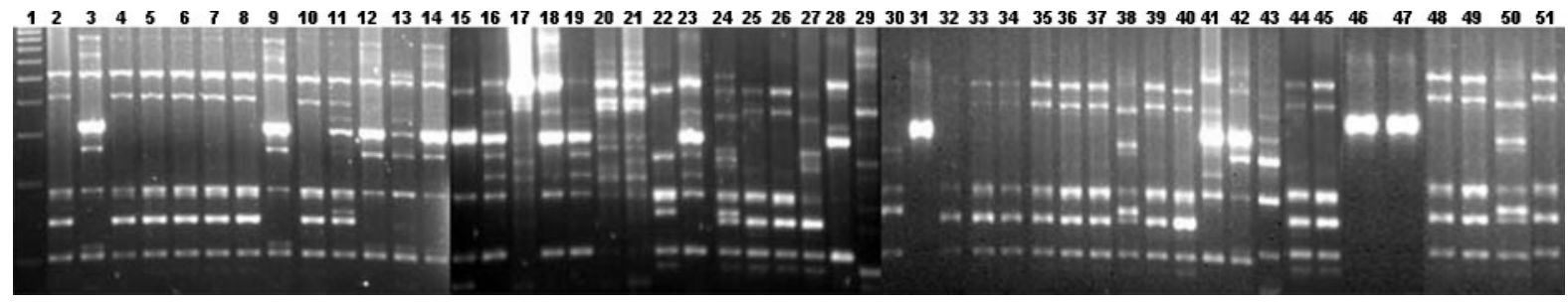

Fig. 1. RAPD fingerprinting of representative clinical isolates of $A$. baumannii including the reference strain $A$. baumannii ATCC $19606^{\top}$. Lanes: 1,500 bp molecular mass marker (Bangalore Genei); 2-14 and 16-51, clinical isolates of $A$. baumannii $(1,2,3,4,5,6,9,10,11,12,13,14,16,17,18,19,20,21,22,23,24,25,26,27,28,29,30,31,32,34,35,36,37,38,39$, $40,41,42,43,45,46,47,49,51,53,55,56$ and 57). Lane 15, A. baumannii ATCC $19606^{\top}$.

employed RAPD because of its simplicity and feasibility (Liu \& Wu, 1997). PFGE, though more efficient in analysing Acinetobacter epidemiology in complex endemic settings (Vila et al., 1996; Liu \& Wu, 1997; D’Agata et al., 2001), is cumbersome as well as expensive and many less well-equipped laboratories may not be able to use this technique routinely.

Carbapenems are the drugs of choice for nosocomial Acinetobacter infections in India. However, in recent years, it has been reported that there is reduced susceptibility to imipenem (Taneja et al., 2003; Joshi et al., 2003a; Sinha et al., 2007; Sinha \& Srinivasa, 2007). Interestingly, many of these reports have documented only moderate resistance to imipenem (Taneja et al., 2003; Sinha \& Srinivasa, 2007). The present study showed high levels of imipenem and meropenem resistance among A. baumannii isolates. Fortyfour per cent of isolates were resistant to meropenem with MIC levels ranging from $16 \mu \mathrm{g} \mathrm{ml}^{-1}$ to $128 \mu \mathrm{g} \mathrm{ml}{ }^{-1}$. However, there was low agreement among the disc diffusion and MIC results for meropenem. Meropenem MIC results showed $60 \%$ of isolates having moderate to complete resistance, while the disc diffusion test showed $89 \%$ resistance. In the present study, $29 \%$ of isolates detected as resistant by disc diffusion were found to have their MICs in the sensitive range. A similar observation was witnessed in a recent study from India (Sinha \& Srinivasa, 2007).

Detection of resistance in pathogens by molecular testing is gaining momentum in India. Many Indian studies have checked for carbapenem resistance in bacteria other than A. baumannii by looking for the presence of extendedspectrum $\beta$-lactamase and MBL genes by PCR (Mendiratta et al., 2005; Sarkar et al., 2006). Amid various MBLencoding genes thus far discovered, $b a_{\mathrm{IMP}}$ and $b l_{\mathrm{VIM}}$ appear to be the most clinically important due to their ability to spread among other major pathogens (Da Silva et al., 2002). In India, recently a high percentage of $P$. aeruginosa strains producing MBL has been reported (Jesudason et al., 2005; Mendiratta et al., 2005; Sarkar et al., 2006). A similarly significant increase in the percentage of A. baumannii isolates $(70.9 \%)$ positive for $\mathrm{MBL}$ production by the EDTA-DDS test was observed in the present study, which is in contrast to the $7.5 \%$ reported in the only other Indian study on MBL production in $A$. baumannii (Gupta et al., 2006), reflecting the evolving scenario in India.

PCR revealed amplification of an $862 \mathrm{bp}$ fragment corresponding to the $b l a_{\mathrm{IMP} 1}$ gene in $42 \%$ of isolates and no isolates showing the presence of $b l a_{\mathrm{VIM} 2}(510 \mathrm{bp}$ ) when tested for MBL genes. Thirteen isolates were positive for MBLs by both the DDS assay and $b l_{\mathrm{IMP1}}$ amplification. There were 10 isolates that were PCR-positive, but negative in the DDS test. Since $b a_{\text {IMP }}$ gene cassettes have been associated with integrons, it is possible that $b a_{\mathrm{IMP}}$ alleles could be carried by Acinetobacter strains but do not phenotypically express the IMP $\beta$-lactamases (Da Silva et al., 2002). Besides, the DDS test showed 26 isolates positive for MBL which did not show amplification for $b l a_{\mathrm{IMP}}$. These isolates were further tested for MBL activity by spectrophotometry, which was positive for 24 isolates wherein cell extracts caused breakdown of imipenem. Specific activity ranged from 41.4 to $60 \mathrm{nmol}$ imipenem hydrolysed $\min ^{-1}$ (mg protein $)^{-1}$, compared to 1.9$13.2 \mathrm{nmol}$ imipenem hydrolysed $\min ^{-1}$ (mg protein $)^{-1}$ by the two MBL-negative isolates used as controls (Table 1). The remaining two DDS-positive isolates displayed no enzyme activity. In the presence of EDTA, hydrolysis measured by spectrophotometry was greatly reduced. These results suggest that other genes might be responsible for encoding MBLs. The DDS test thus proved to be quite reliable and easy to perform.

The carbapenem-resistant strains with no MBL detectable by the DDS test in this study may possess other enzymes mediating carbapenem resistance, such as OXA-type lactamases (class D) or AmpC $\beta$-lactamases, and/or other mechanisms such as outer-membrane permeability and efflux mechanisms that were not checked. The isolates that were MBL-positive by the DDS test but negative for either $b l a_{\mathrm{IMP} 1}$ or $b l a_{\mathrm{VIM} 2}$ amplification may have variant $b l a_{\mathrm{IMP}}$ or $b l a_{\text {SIM }}$ genes. MBL genes are mostly detected in class 1 integron structures and these integrons are detected in a high percentage of Acinetobacter isolates (Seward, 1999; Gallego \& Towner, 2000). The bla $a_{\mathrm{VIM}-2}$ gene cassette has been identified throughout the world as part of class 1 
integrons and is noted to be the most prevalent carbapenemase gene (Poirel et al., 2000; Yum et al., 2002; Walsh et al., 2005). Surprisingly, bla $a_{\mathrm{VIM}-2}$ was not detected in our A. baumannii isolates. Interestingly, one of the latest studies showed $b l a_{\mathrm{VIM}-2}$ only in imipenem-resistant Acinetobacter genomic species 13TU isolates, and not in imipenem-resistant $A$. baumannii isolates, which produced the OXA type of $\beta$-lactamase (Lee et al., 2007). Possibly there may be specific genotypic traits against antimicrobial agents in our A. baumannii isolates too that could lack $b l a_{\mathrm{VIM}-2}$. By acquiring various kinds of resistance mechanisms, A. baumannii has developed into one of the most difficult hospital pathogens to control and treat. The alarming increase in the frequency of MBLs presents an emerging threat of complete resistance to the useful drugs against Acinetobacter spp. in India. Hence restrained and careful use of antibiotics, as well as strict hygiene practices, are critical for preventing the emergence of complete resistance and spread of this pathogen in this country.

\section{REFERENCES}

Chandra, R., Kapil, A., Sharma, P. \& Das, B. (2002). Identification of Acinetobacter species isolated from clinical specimens by amplified ribosomal DNA restriction analysis. Indian J Med Res 116, 1-4.

CLSI (2006). Performance Standards for Antimicrobial Susceptibility Testing, 16th informational supplement. Wayne, PA: Clinical and Laboratory Standards Institute.

D’Agata, E. M., Gerrits, M. M., Tang, Y. W., Samore, M. \& Kusters, J. G. (2001). Comparison of pulsed-field gel electrophoresis and amplified fragment-length polymorphism for epidemiological investigations of common nosocomial pathogens. Infect Control Hosp Epidemiol 22, $550-554$.

Da Silva, G. J., Correia, M., Vital, C., Ribeiro, G., Sousa, J. C., Leitao, R., Peixe, L. \& Duarte, A. (2002). Molecular characterization of $b l a_{\mathrm{IMP}-5}$, a new integron-borne metallo- $\beta$-lactamase gene from an Acinetobacter baumannii nosocomial isolate in Portugal. FEMS Microbiol Lett 215, 33-39.

Edwards, R., Hawkyard, C. V. \& Hashmi, P. S. (1998). Biological assay for the detection of metallo-beta-lactamases in Bacteroides fragilis. $\mathrm{Br} \mathrm{J}$ Biomed Sci 55, 169-171.

Gallego, L. \& Towner, K. J. (2000). Carriage of class I integrons and antibiotic resistance in clinical isolates of Acinetobacter baumannii. In Acinetobacter 2000, 5th International Symposium on the Biology of Acinetobacter, abstract 15. Noordwijkerhout, The Netherlands.

Gerner-Smidt, P., Tjenberg, I. \& Ursing, J. (1991). Reliability of phenotypic tests for identification of Acinetobacter species. J Clin Microbiol 29, 277-282.

Gupta, V., Datta, P. \& Chander, J. (2006). Prevalence of metallo- $\beta$ lactamase (MBL) producing Pseudomonas spp. and Acinetobacter spp. in a tertiary care hospital in India. J Infect 52, 311-314.

Hirakata, Y., Izumikawa, K., Yamaguchui, T., Takemura, H., Tanaka, H., Yoshida, R., Matsuda, J., Nakano, M., Tomono, K. \& other authors (1998). Rapid detection and evaluation of clinical characteristics of emerging multiple-drug-resistant Gram-negative rods carrying the metallo-beta lactamase gene $b l a_{\mathrm{IMP}}$. Antimicrob Agents Chemother 42, 2006-2011.

Jeong, S. H., Kwon Bae, I., Park, K. O., An, Y. J., Sohn, S. G., Jang, S. J., Sung, K. H., Yang, K. S., Lee, K. \& other authors (2006).
Outbreaks of imipenem-resistant Acinetobacter baumannii producing carbapenemases in Korea. J Microbiol 44, 423-431.

Jesudason, M. V., Kandathil, A. J. \& Balaji, V. (2005). Comparison of two methods to detect carbapenemase and metallo-beta-lactamase production in clinical isolates. Indian J Med Res 121, 780-783.

Jones, R. N., Biedenbach, D. J., Sader, H. S., Fritsche, T. R., Toleman, M. A. \& Walsh, T. R. (2005). Emerging epidemic of metallo- $\beta$ lactamase mediated resistances. Diagn Microbiol Infect Dis 51, 77-84.

Joshi, S. G., Litake, G. M., Ghole, V. S. \& Niphadkar, K. B. (2003a). Plasmid borne extended spectrum beta-lactamase in a clinical isolate of Acinetobacter baumannii. J Med Microbiol 52, 1125-1127.

Joshi, S. G., Litake, G. M., Niphadkar, K. B. \& Ghole, V. S. (2003b). Multidrug resistant Acinetobacter baumannii isolates from a teaching hospital. J Infect Chemother 9, 187-190.

Kenchappa, P. \& Sreenivasmurthy, B. (2003). Simplified panel of assimilation tests for identification of Acinetobacter species. Indian $J$ Pathol Microbiol 46, 700-706.

Lauretti, L., Riccio, M. L., Mazzariol, A., Cornaglia, G., Amicosante, G., Fontana, R. \& Rossolini, G. M. (1999). Cloning and characterization of $b l a_{\mathrm{VIM}}$, a new integron-borne metallo-beta-lactamase gene from a Pseudomonas aeruginosa clinical isolate. Antimicrob Agents Chemother 43, 1584-1590.

Lee, K., Yum, J. H., Yong, D., Lee, H. M., Kim, H. D., Docquier, J. D., Rossolini, G. M. \& Chong, Y. (2005). Novel acquired metallo-betalactamase gene, $b l a_{\mathrm{SIM}-1}$, in a class 1 integron from Acinetobacter baumannii clinical isolates from Korea. Antimicrob Agents Chemother 49, 4485-4491.

Lee, J. H., Choi, C. H., Kang, H. Y., Lee, J. Y., Kim, J., Lee, Y. C., Seol, S. Y., Cho, D. T., Kim, K. W., Song, D. Y. \& Lee, J. C. (2007). Differences in phenotypic and genotypic traits against antimicrobial agents between Acinetobacter baumannii and Acinetobacter genomic species 13TU. J Antimicrob Chemother 59, 633-639.

Liu, P. Y. \& Wu, W. L. (1997). Use of different PCR-based DNA fingerprinting techniques and pulsed-field gel electrophoresis to investigate the epidemiology of Acinetobacter calcoaceticusAcinetobacter baumannii complex. Diagn Microbiol Infect Dis 29, 19-28.

Manikal, V. M., Landman, D., Saurina, G., Oydna, E., Lal, H. \& Quale, J. (2000). Endemic carbapenem-resistant Acinetobacter species in Brooklyn, New York: citywide prevalence, inter-institutional spread, and relation to antibiotic usage. Clin Infect Dis 31, 101-106.

Mendiratta, D. K., Deotale, V. \& Narang, P. (2005). Metallo-betalactamase producing Pseudomonas aeruginosa in a hospital from a rural area. Indian J Med Res 121, 701-703.

Navon-Venezia, S., Ben-Ami, R. \& Carmeli, Y. (2005). Update on Pseudomonas aeruginosa and Acinetobacter baumannii infections in the healthcare setting. Curr Opin Infect Dis 18, 306-313.

Peleg, A. Y., Franlin, C., Bell, J. M. \& Spelman, D. W. (2005). Dissemination of metallo- $\beta$-lactamase gene $b a_{\mathrm{IMP}-4}$ among gram negative pathogens in a clinical setting in Australia. Clin Infect Dis 41, 1549-1556.

Poirel, L., Naas, T., Nicolas, D., Collet, L., Bellais, S., Cavallo, J. D. \& Nordmann, P. (2000). Characterization of VIM-2, a carbapenemhydrolyzing metallo- $\beta$-lactamase and its plasmid- and integron-borne gene from a Pseudomonas aeruginosa clinical isolate in France. Antimicrob Agents Chemother 44, 891-897.

Prashanth, K. \& Badrinath, S. (2000). Simplified phenotypic tests for identification of Acinetobacter spp. and their antimicrobial susceptibility status. J Med Microbiol 49, 773-778.

Prashanth, K. \& Badrinath, S. (2004). In vitro susceptibility pattern of Acinetobacter species to commonly used cephalosporins, quinolones and aminoglycosides. Indian J Med Microbiol 22, 97-103. 
Prashanth, K. \& Badrinath, S. (2005). Epidemiological investigation of nosocomial Acinetobacter infections using AP-PCR and pulse field gel electrophoresis. Indian J Med Res 122, 408-418.

Prashanth, K. \& Badrinath, S. (2006). Nosocomial infections due to Acinetobacter species: clinical findings, risk and prognostic factors. Indian J Med Microbiol 24, 39-44.

Sarkar, B., Biswas, D., Prasad, R. \& Sharma, J. P. (2006). A clinicomicrobiological study on the importance of Pseudomonas in nosocomially infected ICU patients, with special reference to metallo beta-lactamase production. Indian J Pathol Microbiol 49, 44-48.

Seward, R. J. (1999). Detection of integrons in worldwide nosocomial isolates of Acinetobacter spp. Clin Microbiol Infect 5, 308-318.

Sinha, M. \& Srinivasa, H. (2007). Mechanisms of resistance to carbapenems in meropenem resistant Acinetobacter isolates from clinical samples. Indian J Med Microbiol 25, 121-125.

Sinha, M., Srinivasa, H. \& Macaden, R. (2007). Antibiotic resistance profile and extended spectrum beta-lactamase (ESBL) production in Acinetobacter species. Indian J Med Res 126, 63-67.

Taneja, N., Maharwal, S. \& Sharma, M. (2003). Imipenem resistance in nonfermenters causing nosocomial urinary tract infections. Indian J Med Sci 57, 294-299.
Vila, J., Marcos, M. A. \& Jimenez de Anta, M. T. (1996). A comparative study of different PCR-based DNA fingerprinting techniques for typing of the Acinetobacter calcoaceticus-A. baumannii complex. J Med Microbiol 44, 482-489.

Walsh, T. R., Toleman, M. A., Poirel, L. \& Nordmann, P. (2005). Metallo-beta-lactamases: the quiet before the storm? Clin Microbiol Rev 18, 306-325.

Yano, H., Kuga, A., Okamoto, R., Kitasato, H., Kobayashi, T. \& Inoue, M. (2001). Plasmid-encoded metallo- $\beta$-lactamase (IMP-6) conferring resistance to carbapenems, especially meropenem. Antimicrob Agents Chemother 45, 1343-1348.

Yong, D., Lee, K., Yum, J. H., Shin, H. B., Rossolini, G. M. \& Chong, Y. (2002). Imipenem-EDTA disk method for differentiation of metallo$\beta$-lactamase producing clinical isolates of Pseudomonas spp. and Acinetobacter spp. J Clin Microbiol 40, 3798-3801.

Yum, J. H., Yi, K., Lee, H., Yong, D., Lee, K., Kim, J. M., Rossolini, G. M. \& Chong, Y. (2002). Molecular characterization of metallo- $\beta$ lactamase-producing Acinetobacter baumannii and Acinetobacter genomospecies 3 from Korea: identification of two novel integrons carrying blaVIM-2 gene cassettes. J Antimicrob Chemother 49, 837840. 